\title{
Genome Analysis of Melon Necrotic Spot Virus Incursions and Seed Interceptions in Australia
}

\author{
Joanne Mackie, ${ }^{1}$ Ellena Higgins, ${ }^{2}$ Grant A. Chambers, ${ }^{3}$ Len Tesoriero, ${ }^{3}$ Ramez Aldaoud, ${ }^{1}$ Geoff Kelly, ${ }^{1}$ Wycliff M. Kinoti, ${ }^{1}$ \\ Brendan C. Rodoni, ${ }^{1}$ and Fiona E. Constable ${ }^{1, \dagger}$ \\ ${ }^{1}$ Agriculture Victoria Research, Department of Jobs, Precincts and Regions, AgriBio, Bundoora, Victoria 3083, Australia \\ ${ }^{2}$ Department of Biochemistry and Genetics, La Trobe Institute for Molecular Science, La Trobe University, Bundoora, Victoria \\ 3086, Australia \\ ${ }^{3}$ New South Wales Department of Primary Industries, Elizabeth Macarthur Agricultural Institute, Menangle, New South Wales \\ 2568, Australia
}

\begin{abstract}
Melon necrotic spot virus (MNSV) was detected in field-grown Cucumis melo (rockmelon) and Citrullus lanatus (watermelon) plants in the Sunraysia district of New South Wales and Victoria, Australia, in 2012, 2013, and 2016, and in two watermelon seed lots tested at the Australian border in 2016. High-throughput sequencing was used to generate near full-length genomes of six isolates detected during the incursions and seed testing. Phylogenetic analysis of the genomes suggests that there have been at least two incursions of MNSV into Australia and none of the field isolates were the same as the isolates detected in seeds. The analysis indicated that one watermelon field sample (L10), the Victorian rockmelon field sample, and two seed interception samples may have European origins. The results showed that two isolates (L8 and L9) from watermelon were divergent from the type MNSV strain (MNSV-GA, D12536.2) and had 99\% nucleotide identity to two MNSV isolates from human stool collected in the United States (KY124135.1, KY124136.1). These isolates also had high nucleotide pairwise identity $(96 \%)$ to a partial sequence from a Spanish MNSV
\end{abstract}

Abstract isolate (KT962848.1). The analysis supported the identification of three previously described MNSV genotype groups: EU-LA, Japan melon, and Japan watermelon. To account for the greater diversity of hosts and geographic regions of the MNSV isolates used in this study, it is suggested that the genotype groups EU-LA, Japan melon, and Japan watermelon be renamed to groups I, II, and III, respectively. The divergent isolates L8 and L9 from this study and the stool isolates from the United States formed a fourth genotype group, group IV. Soil collected from the site of the Victorian rockmelon MNSV outbreak was found to contain viable MNSV and the virus vector, a chytrid fungus, Olpidium bornovanus (Sahtiyanci) Karling, 18 months after the initial MNSV detection. This is a first report of O. bornovanus from soil sampled from an MNSV-contaminated site in Australia.

Keywords: genome analysis, genotypes, Melon necrotic spot virus, MNSV, Olpidium bornovanus, pathogen diversity, rockmelon, viruses and viroids, watermelon
Melon necrotic spot virus (MNSV) is the type species of the genus Gammacarmovirus in the family Tombusviridae (Hibi and Furuki 1985; Riviere and Rochon 1990; Scheets et al. 2016). MNSV was first described in Japan and was found in melon (Cucumis melo) plants with necrotic spot symptoms (Kishi 1966). MNSV has subsequently been found in many other countries in Asia (Gu et al. 2008; Kishi 1966; Kubo et al. 2005; Matsuo et al. 1991; Yoshida et al. 1980), Africa (Yakoubi et al. 2008), Europe (Avgelis 1989; Bos et al. 1984; Tomlinson and Thomas 1986), Central America (de Cara et al. 2008; Herrera-Vásquez et al. 2010), North America (Gonzalez-Garza et al. 1979; Li et al. 2015), and South America (Moura et al. 2018). The virus primarily infects melon (Cucumis melo), cucumber (Cucumis sativa) (Tomlinson and Thomas 1986), and watermelon (Citrullus lanatus) (Ruiz et al. 2016; Sela et al. 2013) but there have been occasional reports of infected pumpkin (Cucurbita maxima), squash (Cucurbita pepo) (Ali et al. 2012a, b), fluted pumpkin (Telfairia occidentalis), and bottle gourd (Lagenaria siceraria) (Ayo-John et al. 2014).

Typical symptoms associated with MNSV infection include stem necrosis at the crown level and necrotic spots on leaves and fruits

${ }^{\dagger}$ Corresponding author: F. E. Constable;

Fiona.Constable@ecodev.vic.gov.au

*The $\boldsymbol{e}$-Xtra logo stands for "electronic extra" and indicates that three supplementary figures and seven supplementary tables are published online.

The author(s) declare no conflict of interest.

Accepted for publication 13 February 2020.

(c) 2020 The American Phytopathological Society
(Gonzalez-Garza et al. 1979; Kishi 1966). Significant losses of fruit yield and quality are observed in glasshouse and field crops of cucumber, melon, and watermelon, leading to economic losses (Bos et al. 1984; Köklü and Yilmaz 2006; Tomassoli and Barba 2000). Transmission of MNSV occurs naturally in the soil by zoospores of the chytrid fungus Olpidium bornovanus (Sahtiyanci) Karling. $O$. bornovanus acquires MNSV from the soil or water, independent of the plant root system by adsorption of the virus particle onto the zoospore surface. The fungus creates cysts on the plant roots, acquiring the virus from or transmitting the virus to the root cells of the parasitized plant (Rochon 2009). MNSV is also seedborne and is mechanically transmitted to seedlings at low levels or at higher levels in the presence of $O$. bornovanus (Campbell et al. 1996).

MNSV particles have a spherical morphology, approximately $30 \mathrm{~nm}$ in diameter, and contain a single molecule of positive-sense, single-stranded RNA of approximately 4,266 nucleotides (nt) (Hibi et al. 1980). The genome consists of at least five open reading frames (ORFs) that are preceded by a $5^{\prime}$-untranslated region (UTR) and followed by a nonpolyadenylated 3 '-UTR. Translation of the $5^{\prime}$-proximal ORF yields proteins p29 and the read-through product p89 (the putative RNA-dependent RNA polymerase [RdRp]). Two centrally located ORFs, also known as the double gene block, encode for proteins $\mathrm{p} 7 \mathrm{~A}$ and $\mathrm{p} 7 \mathrm{~B}$ and are involved in cell-to-cell movement of virus. The 3'-proximal ORF encodes for the coat protein $(\mathrm{CP})$, $\mathrm{p} 42$, and is essential for virus attachment to zoospores of $O$. bornovanus and the fungal transmission of the MNSV (Ohki et al. 2010; Riviere and Rochon 1990). Current taxonomy to differentiate species within the genus Gammacarmovirus in the family Tombusviridae is based on analysis of the RdRp and CP amino acid sequences (demarcation criteria of $<75 \%$ amino acid sequence similarity for both coding regions), although International Committee on Taxonomy of 
Viruses-ratified modifications to the genus demarcation criteria suggest that the RdRp coding region is more informative than other virus proteins (Scheets et al. 2015, 2016).

Management of MNSV-induced disease in melon production is achieved using clean, virus-tested seed, control of the fungal vector, crop rotation to reduce viral and fungal load, and the use of resistant cultivars (Louws et al. 2010; Tomassoli and Barba 2000). The inclusion of the single recessive resistance gene $n s v$, which encodes melon eukaryotic translation initiation factor 4E (Cm-eIF4E) (Coudriet et al. 1981; Nieto et al. 2006), or Mnr-1, Mnr-2, two dominant genes from the resistant cultivar Doublon (Mallor et al. 2003; Mallor Giménez et al. 2003), into cultivar hybrids have made a significant contribution to the control of MNSV in production areas overseas. The Spanish isolates, MNSV 264 and MNSV-N, are able to overcome $n s v$ resistance in melons, and MNSV264 was also found to infect noncucurbit hosts (Díaz et al. 2002, 2004; Miras et al. 2014).

Incursions of exotic pathogens such as MNSV can significantly impact the biosecurity of the melon industry, affecting production of and domestic and international market access to fruit. MNSV was not known to occur in Australia until 2012, when fruit and stem necrosis symptoms were observed on watermelon plants growing in the Sunraysia region of New South Wales, and the presence of MNSV was confirmed by two Australian diagnostics laboratories (Elizabeth Macarthur Agricultural Institute [EMAI] in New South Wales and the Centre for AgriBioscience [AgriBio] in Victoria). Further detections occurred on watermelon in New South Wales in 2013 and rockmelon in Victoria in 2016 (EMAI and AgriBio). The outbreaks caused significant economic losses of up to $100 \%$ to the affected growers as a result of poor fruit quality associated with necrosis. Because of the outbreaks and to reduce the quarantine risk, the Australian Department of Agriculture and Water Resources introduced emergency measures in 2016 requiring preborder or border testing of imported cucurbit seeds for MNSV and additional detections were made from imported seed. This study describes the characterization of the full-length genomes determined for three watermelon MNSV isolates from the incursions in New South Wales, one Victorian MNSV melon isolate, and two watermelon seed interception isolates. It also describes the detection of $O$. bornovanus on affected farms and its ability to transmit the Victorian isolate of MNSV.

\section{Materials and Methods}

Virus isolates. Six MNSV isolates were used in this study (Table 1). Four leaf and stem samples that presented necrotic spots in fruit, stem, and/or leaves were obtained from disease outbreaks in watermelon and rockmelon crops grown in the Sunraysia region of Australian, an intensive horticultural production region that covers south eastern New South Wales and north western Victoria. Two watermelon samples (cultivars Nightshade and Royal Armada) were collected from New South Wales in 2012, one watermelon sample (cultivar unknown) was collected in New South Wales in 2013, and five rockmelon leaf and fruit samples (cultivar Jaipur) were collected from Victoria in 2016. Material from these outbreak sites was found to be positive for MNSV using reverse transcription PCR (RTPCR) amplification when tested by two Australian diagnostic laboratories (EMAI in New South Wales and AgriBio in Victoria). In 2016, additional isolates were obtained from two imported seed lots in which MNSV had been detected during mandatory testing at the Australian border using enzyme-linked immunosorbent assay (ELISA) and confirmed by RT-PCR at AgriBio.
RNA extraction and RT-PCR amplification. Total RNA was extracted from each plant sample using the RNeasy Plant Mini Kit (QIAGEN, Doncaster, Victoria, Australia) with a modified lysis buffer (MacKenzie et al. 1997). Watermelon seed samples were crushed and homogenized in $5 \times$ phosphate-buffered saline containing $0.25 \%$ (vol/ $/ \mathrm{vol}$ ) Tween-20 and $2 \%$ (wt/vol) polyvinylpyrrolidone 40,000 , which was added at the rate of $9 \mathrm{ml}$ for each $1 \mathrm{~g}$ of seed. RNA was extracted according to the manufacturer's instructions using $100 \mu l$ of the seed homogenate with $450 \mu l$ of RLT buffer provided in the RNeasy kit.

RT-PCR tests were carried out using the SuperScript III One-Step RT-PCR System with Platinum Taq Polymerase (Invitrogen, Carlsbad, CA) according to the manufacturer's instructions except that the total reaction volume was $25 \mu \mathrm{l}$. RNA extracts were tested for the presence of virus species in the genera Alphacarmovirus, Betacarmovirus, and Gammacarmovirus using a generic carmovirus assay and for MNSV using species-specific primers (HerreraVásquez et al. 2009a; Zheng et al. 2011; Supplementary Table S1). The PCR products were analyzed by electrophoresis in $1.5 \%$ agarose gel stained with SYBR Safe DNA gel stain (Invitrogen). Fragment sizes were determined by comparison against $1 \mathrm{~Kb}$ plus DNA ladder (Invitrogen).

DNA extraction and amplification. DNA was extracted from root samples $(0.5 \mathrm{~g})$ using the DNeasy Plant Mini Kit (QIAGEN) as per the manufacturer's instructions except that a CTAB homogenization buffer was used (Green et al. 1999). PCR was performed to test for the presence of $O$. bornovanus using species-specific primers (Herrera-Vásquez et al. 2009b; Supplementary Table S1) and Platinum Taq DNA polymerase (Invitrogen, Mount Waverley, Victoria, Australia) according to the manufacturer's instructions except that the total reaction volume was $25 \mu \mathrm{l}$ and 1.0 unit of Platinum Taq DNA polymerase was used in each reaction.

High-throughput sequencing library preparations and sequence reads analysis. To sequence the full genome of the seed and field MNSV isolates, metagenomic high-throughput sequencing (HTS) libraries were prepared as described previously (Kinoti et al. 2017a). The resulting libraries were sequenced using the Illumina MiSeq with a paired read length of $2 \times 251 \mathrm{bp}$. The generated raw sequence reads were quality trimmed, paired, and assembled into contigs and BLASTn analysis (Altschul et al. 1997) of the assembled contigs was carried out as previously described (Kinoti et al. 2017a, b). The assembled virus contig sequences were submitted to GenBank and the accession number of each virus RNA sequence is included in Supplementary Table S2.

Genome walking, cloning, and Sanger sequencing. To confirm the presence of MNSV detected using HTS analysis, primers were designed from the full genome contig assemblies of each isolate. The OligoAnalyzer Tool (Integrated DNA Technologies OligoAnalyzer version 1.5) and Primer-BLAST (https://www.ncbi.nlm.nih. gov/tools/primer-blast/) were used to design primer pairs that would amplify overlapping 1,000-bp target regions of the virus isolate (Supplementary Table S3).

RT-PCR products that were equal or similar to the expected size were purified using the QIAquick PCR purification kit and cloned using the pGEM-T Easy Vector System (Promega) as previously described (Sambrook et al. 1989). Clones of each PCR product were sequenced in both directions using primers SP6 and T7 and the ABI PRISM BIGDYE Terminator Cycle Sequencing Kit version

Table 1. Melon necrotic spot virus (MNSV) isolates characterized in this study, the year and location they were collected from, and the host and host tissue type in which they were detected

\begin{tabular}{llll}
\hline MNSV isolate name & Year & \multicolumn{1}{c}{ Location } & \multicolumn{1}{c}{ Host } \\
\hline L8 & 2012 & New South Wales & Watermelon (Citrullus lanatus 'Nightshade') on unknown rootstock \\
L9 & 2013 & New South Wales & Watermelon (Citrullus lanatus 'Royal Armada') on Emphasis rootstock \\
L10 & 2012 & New South Wales & Watermelon (Citrullus lanatus), cultivar unknown \\
Vic Melon & 2016 & Victoria & Rockmelon (Cucumis melo 'Jaipur') \\
3948 & 2016 & Imported seed & Watermelon (Citrullus lanatus), cultivar unknown \\
3954 & 2016 & Imported seed & Watermelon (Citrullus lanatus), cultivar unknown \\
\hline
\end{tabular}


3.1 (Applied Biosystems). Resulting overlapping Sanger sequences were assembled to near full-length genomes using Geneious (version 11.0; Biomatters) and were used to confirm the HTS-assembled MNSV full genome sequences.

Sequence identity analysis. Sequence identity comparison using the sequence demarcation tool (SDT) (version 1.2) (Muhire et al. 2014) was carried out on the aligned MNSV full genome sequences (Supplementary Table S4) and coat protein and polymerase amino acid sequences. Assembled MNSV genomes from this study were also tested against viral genomes in the NCBI database using the Pairwise Sequence Comparison (PASC) tool (Bao et al. 2014).

Phylogenetic analysis. The full-length genome, coat protein, and polymerase sequences of Australian MNSV isolates assembled from metagenomic HTS in this study and MNSV full genome sequences of isolates from various plant host species and geographical regions retrieved from GenBank (Supplementary Table S4) were aligned using MUSCLE (version 3.8.31) (Edgar 2004). Maximum likelihood (ML) phylogenetic trees were constructed in MEGA (version 6) (Tamura et al. 2013) with 1,000 bootstrap replicates and the resulting trees were visualized in FigTree (version 1.4.2) (Rambaut 2012).

Bayesian inference, using full genomes, was also used to estimate the phylogenetic relationships of the full genome of Australian MNSV isolate sequences from this study and strain sequences from other countries (Supplementary Table S4). The most suitable evolutionary models were determined by jModelTest (Darriba et al. 2012), and the Bayesian analysis was carried out using MrBayes 3.2.2 (Ronquist et al. 2012). MrBayes was run for 50 million generations on four chains, with trees sampled every 1,000 generations using $\mathrm{GTR}+\mathrm{I}+\mathrm{G}$ as the evolutionary model. In each of the runs, the first $25 \%(2,500)$ of the sampled trees were discarded as burn-in. Convergence and mixing of the chains were evaluated using Tracer version 1.6 (Rambaut et al. 2014) and trees were visualized using FigTree (Rambaut 2012) (http://tree.bio.ed.ac.uk/software/figtree/).

Recombination analysis. The alignment of the full genome of Australian MNSV genome sequences from this study and genome sequences of isolates from GenBank (Supplementary Table S4) was assessed for evidence of recombination. RDP version 4.9 (Martin et al. 2015) was used to detect putative recombination breakpoints between these sequences. Default parameters were used for the seven recombination detection methods implemented in RDP4.9: RDP (Martin et al. 2005), 213 GENECONV (Padidam et al. 1999), Bootscan (Martin et al. 2005), MaxChi (Smith 1992), Chimaera (Posada 2002), 3Seq (Boni et al. 2007), and SiScan (Gibbs et al. 2000). A Bonferroni-corrected $P$ value $<0.05$ for four or more recombination detection methods was considered credible evidence of a recombination event (Ohshima et al. 2002). Recombination signals were disregarded if they were flagged by RDP4.9 as potentially arising through evolutionary processes other than recombination were disregarded.

Sequence assessment for resistance-breaking regions. To assess whether the Australian MNSV isolates are likely to be resistance breaking, the 3'-UTR region of each isolate was screened for the presence of the virulence determinants identified in resistance-breaking isolates MNSV-264 (GenBank accession AY330700) (Díaz et al. 2002) and MNSV-N (GenBank accession KF060715) (Miras et al. 2014). The full-length genome alignment generated for phylogenetic analysis was used to screen the 3'-UTR of MNSV-264 (GenBank accession AY330700), avirulent type isolate MNSV-GA (GenBank accession D12536), and the six Australian isolates for the virulence determinant regions and stem loop regions as described (Truniger et al. 2008) as well as the 55-nt insert at the 5'-proximal end of the 3'-UTR of MNSV-N that closely matches Cucurbit aphid-borne yellows virus (CABYV) as described (Miras et al. 2014).

Soil sampling. In 2017, three 500-g soil samples were randomly collected from the site of the Victorian MNSV outbreak in rockmelon. These samples were used in subsequent baiting experiments to determine whether viable MNSV and the vector, O. bornovanus, were present in soil 18 months after the initial MNSV detection. Soil sampled from the New South Wales MNSV outbreak in 2013 was used in separate baiting experiments.
Isolation of $O$. bornovanus and MNSV from soil with bait plants. Seed of the MNSV sensitive rockmelon cultivar Jaipur was used for this study. A 2,000-seed sample was divided into subsamples of 100 seeds and tested by RT-PCR (Herrera-Vásquez et al. 2009a) to ensure that it was not contaminated with MNSV prior to planting. Thirty seeds from the remaining MNSV-negative seed lot were sown in potting mix blended with an equal volume of soil from each of the soil samples collected from the MNSV-contaminated site. As a control, the same number of seeds were also planted in trays containing soil-free potting mix only or vermiculite. These controls were included to ensure that the detection of $O$. bornovanus and MNSV in seedlings was not a result of seed contamination.

At 2 and 4 weeks postseedling emergence, the roots of at least five seedlings were examined by light microscopy for the presence of resting spores and/or zoosporangia of $O$. bornovanus. Samples of hair root tissue, about 5 to $10 \mathrm{~mm}$ long, were mounted in a lactofuchsin solution with $0.1 \%$ acid-fuchsin in $100.0 \mathrm{ml}$ of lactic acid (85\%) and examined using an Olympus BX51 System Microscope at 400× (Carmichael 1955). A Leica DFC295 camera was attached to the same microscope and used to take photographs. At the same time, five seedlings were collected from each of the three trays containing contaminated soil/potting mix and five seedlings were collected from the sterile potting mix and the vermiculite controls. These seedlings were tested for $O$. bornovanus and MNSV using PCR and RT-PCR, respectively.

Seeds of Citrullus lanatus 'Candy Red' and 'Sugar Sweet' were planted in the soil from Dareton, New South Wales. Roots of these plants were observed, and extracted DNA was screened for $O$. bornovanus using PCR (Herrera-Vásquez et al. 2009b). Roots of sample L9 (watermelon cultivar Royal Armada on Emphasis rootstock) collected from the same site as the soil sample were also examined by light microscopy for the presence $O$. bornovanus.

\section{Results}

MNSV detection in field collected samples and seed. MNSV was detected in three leaf samples and two fruit samples of the rockmelon plant cultivar Jaipur (isolate Vic Melon) and in one New South Wales watermelon leaf sample (isolate L10) using the MNSVspecific and genus-specific RT-PCR tests (Herrera-Vásquez et al. 2009a; Zheng et al. 2011; Supplementary Table S1). The specific MNSV RT-PCR confirmed the presence of MNSV in watermelon seeds (isolates 3948 and 3954) that had previously tested positive using a commercial MNSV ELISA kit during border testing. The presence of MNSV was confirmed by Sanger sequencing of the RT-PCR products. The sequences from MNSV isolates Vic Melon, L10, 3948, and 3954 shared a 94 to $95 \%$ nucleotide sequence identity with the same region of the CP of the MNSV type isolate (GenBank accession D12536.2).

MNSV was not detected in leaf tissue samples of two symptomatic watermelon plants, cultivars Nightshade (isolate L8) and Royal Armada (isolate L9), using the MNSV-specific RT-PCR test. However, an MNSV-like virus was detected using the genera-specific RT-PCR test and sequencing of the resulting 849-bp PCR product showed that the virus shared $76 \%$ nucleotide sequence identity with the same region of the RdRp of the MNSV type isolate (GenBank accession D12536.2).

HTS and Sanger sequencing. Genomes of the six Australian MNSV isolates detected by RT-PCR in this study were determined using HTS. The total raw sequence reads obtained from the six samples ranged from $1,161,117$ to $2,011,760$ and the read numbers were reduced to $1,152,950$ to $2,005,987$ reads after quality trimming (Table 2). SPAdes (Bankevich et al. 2012) was used for de novo assembly of the sequence reads from each individual plant sample and 1,395 to 4,205 scaffolds across the six samples were obtained (Table 2). A BLASTn search of the GenBank database (Altschul et al. 1997) revealed a single scaffold for each MNSV isolate covering the full genome of MNSV with an identity range of 79 to $96 \%$ to MNSV type isolate and with a mean coverage range of 291 to 436 times (Table 2).

The primers that were designed to confirm the presence of Australian MNSV isolates detected by HTS generated PCR products of the 
expected size (Supplementary Table S3). Sanger sequencing of the cloned PCR products confirmed the sequence arrangement of the genome of each MNSV isolate analyzed in this study.

Sequence identity analysis. Two distinct groups of Australian MNSV isolates were formed when their full-length or near fulllength genomes assembled from metagenomic HTS in this study were compared against one another and GenBank isolates using SDT and PASC analyses. The L8 and L9 isolates shared 99\% nucleotide identity. The remaining four isolates shared 95 to $99 \%$ nucleotide identity with each other, but they only shared $66 \%$ nucleotide identity with isolates L8 and L9 (Table 3).

When compared with genome sequences of MNSV from GenBank (Supplementary Table S4), Australian isolates 3948, 3954, Vic Melon, and L10 had the greatest nucleotide similarity (SDT, 97\%; and PASC, 95 to 96\%) to the Spanish MNSV-Al isolate (GenBank accession DQ339157). Isolates L8 and L9 had the greatest nucleotide similarity (SDT, 99\%; and PASC, 98 to 99\%) with USA/
MNSV/2014 (GenBank accession KY124135.1) (Supplementary Fig. S1).

The SDT and PASC nucleotide analysis showed the formation of five groups (I, II, III, IV, and V) of MNSV isolates, with the fifth group containing a single isolate Malfa5 (GenBank accession AY122286). Australian isolates L10, Vic Melon, 3948, and 3954 clustered with mainly European and Latin American cucumber and melon isolates in group I. Isolates in this group shared 89 to $100 \%$ nucleotide pairwise identity. Japanese melon isolates formed group II and isolates in this group shared 96 to $97 \%$ nucleotide identity. Group III, comprising South Korean and Japanese MNSV isolates from watermelon, shared 96 to $98 \%$ nucleotide identity. Isolates L8 and L9 formed group IV, together with two MNSV/USA isolates from human stool samples (GenBank accessions KY124135 and KY124136). Isolates in group IV shared 98 to $100 \%$ nucleotide identity. Group I shared 84 to $87 \%, 72$ to $75 \%, 68$ to $70 \%$, and 87 to $89 \%$ nucleotide pairwise identity with each of the groups II, III, IV, and V,

Table 2. Number of raw reads generated from high-throughput sequencing, number of reads after quality trimming, number of scaffolds generated by de novo assembly, percentage BLASTn identity to the Melon necrotic spot virus (MNSV) type isolate, genome size of assembled MNSV isolates from this study, and average coverage of each genome assembled

\begin{tabular}{|c|c|c|c|c|c|c|}
\hline Isolate ID & $\begin{array}{l}\text { NGS raw } \\
\text { reads }(n)^{\mathrm{a}}\end{array}$ & $\begin{array}{c}\text { Reads after } \\
\text { trimming }(n)\end{array}$ & Scaffolds (n) & $\begin{array}{l}\text { BLASTn identity to } \\
\text { MNSV type isolate (\%) }\end{array}$ & $\begin{array}{l}\text { Scaffold } \\
\text { size (bp) }\end{array}$ & $\begin{array}{l}\text { Average } \\
\text { coverage }\end{array}$ \\
\hline L8 & $1,726,743$ & $1,719,766$ & 1,998 & 76 & 4,219 & 373 \\
\hline L9 & $2,011,760$ & $2,005,987$ & 4,205 & 76 & 4,216 & 436 \\
\hline L10 & $1,856,432$ & $1,850,459$ & 3,135 & 96 & 4,228 & 332 \\
\hline Vic Melon & $1,843,064$ & $1,837,291$ & 2,252 & 96 & 4,228 & 415 \\
\hline 3948 & $1,161,117$ & $1,152,950$ & 1,395 & 96 & 4,218 & 291 \\
\hline 3954 & $1,467,755$ & $1,463,003$ & 1,596 & 95 & 4,227 & 256 \\
\hline
\end{tabular}

${ }^{a}$ NGS = next-generation sequencing.

Table 3. Percentage of nucleotide identity between full-length or near full length genomes of Australian and other Melon necrotic spot virus isolates from GenBank

\begin{tabular}{|c|c|c|c|c|c|c|c|c|c|c|c|c|c|c|}
\hline Isolate $^{\mathbf{a}}$ & $\begin{array}{c}\text { DQ } \\
339157\end{array}$ & $\underset{\mathbf{3 3 0 7 0 0}}{\mathbf{A Y}}$ & 3948 & $\begin{array}{c}\text { DQ } \\
922807\end{array}$ & L10 & $\begin{array}{c}\text { Vic } \\
\text { Melon }\end{array}$ & 3954 & $\underset{12536}{D}$ & $\underset{29671}{M}$ & $\begin{array}{c}\text { KF } \\
060715\end{array}$ & $\begin{array}{c}\text { MG } \\
030690\end{array}$ & $\begin{array}{c}\text { KR } \\
094068\end{array}$ & $\underset{124137}{K Y}$ & $\begin{array}{c}\text { GU } \\
480022\end{array}$ \\
\hline DQ339157 Muskmelon Spain (I) & & 91 & 96 & 96 & 96 & 96 & 95 & 96 & 96 & 94 & 94 & 95 & 94 & 95 \\
\hline AY330700 Melon Spain (I) & & & 90 & 90 & 90 & 90 & 89 & 90 & 90 & 87 & 88 & 89 & 88 & 89 \\
\hline 3948 Watermelon Australia (I) & & & & 95 & 96 & 96 & 95 & 95 & 95 & 93 & 94 & 94 & 94 & 94 \\
\hline DQ922807 Melon Israel (I) & & & & & 95 & 95 & 94 & 95 & 94 & 93 & 93 & 94 & 93 & 94 \\
\hline L10 Watermelon Australia (I) & & & & & & 99 & 96 & 95 & 95 & 93 & 94 & 94 & 95 & 94 \\
\hline Vic Melon Australia (I) & & & & & & & 96 & 95 & 95 & 93 & 94 & 94 & 95 & 94 \\
\hline 3954 Watermelon Australia (I) & & & & & & & & 95 & 95 & 93 & 94 & 94 & 94 & 94 \\
\hline D12536 Cucumber Netherlands (I) & & & & & & & & & 100 & 93 & 94 & 95 & 94 & 95 \\
\hline M29671 Cucumber Netherlands(I) & & & & & & & & & & 93 & 94 & 95 & 94 & 95 \\
\hline KF060715 Cucurbitaceae Spain (I) & & & & & & & & & & & 95 & 96 & 93 & 93 \\
\hline MG030690 Muskmelon Brazil (I) & & & & & & & & & & & & 96 & 94 & 93 \\
\hline KR094068 Cucumber Canada (I) & & & & & & & & & & & & & 94 & 94 \\
\hline KY124137 Human stool USA (I) & & & & & & & & & & & & & & 94 \\
\hline
\end{tabular}

GU480022 Muskmelon China (I)

KX883146 Diptera China (I)

KY264755 Melon China (I)

AB250685 Melon Japan (II)

AB250686 Melon Japan II)

AB189943 Muskmelon Japan II)

AB250684 Melon Japan II)

AB189944 Muskmelon Japan II)

AB250687 Melon Japan II)

AY122286 Melon Spain (V)

AB232925 Watermelon Japan (III)

AB232926 Watermelon Japan (III)

LC314587 Watermelon South Korea (III)

LC314588 Watermelon South Korea (III)

LC314589 Watermelon South Korea (III)

KY123135 Human stool USA (IV)

KY124136 Human stool USA (IV)

L8 Watermelon Australia (IV)

L9 Watermelon Australia (IV)

${ }^{a}$ I, II, III, IV, and V denote isolate groups from the full genome phylogenetic tree. 
respectively. Isolates in group II shared 73,68 , and $86 \%$ nucleotide identity with groups III, IV, and V, respectively. Isolates in group III shared 69 and $72 \%$ nucleotide identity with groups IV and V, respectively. Isolates in group IV shared 64 to $65 \%$ nucleotide identity with the isolate in group V.

SDT identity analysis of the aligned polymerase amino acid sequences showed similar groupings as the full genome nucleotide sequences, whereas only three groupings were observed for CP amino acid sequences (Supplementary Figs. S2 and S3).

Recombination and phylogenetic analysis. Recombination analysis of full genome sequences of the Australian MNSV isolates from this study did not identify any recombinants (Supplementary Table S5); therefore, all MNSV isolate sequences were used for phylogenetic analysis. This study used the ML trees to infer the MNSV isolate relationship because Bayesian inference and ML phylogenetic analyses generated trees with similar topologies and ML trees were used previously in taxonomic demarcation of the Alphacarmovirus, Betacarmovirus, and Gammacarmovirus genera (Scheets et al. 2016).

Phylogenetic analysis of the aligned full genome nucleotide sequences identified that there were five distinct genotype groups of MNSV strains (Fig. 1). All groups had $>99 \%$ bootstrap support. Group I included Australian isolates 3948, 3954, Vic Melon, and L10 together with isolates from China (Diptera and Muskmelon), Israel (melon), the Netherlands (cucumber), Spain (Muskmelon), and the United States (Human stool). Groups II and III clustered melon isolates from Japan and watermelon isolates from Japan and South Korea, respectively. Group IV comprised the Australian watermelon seed isolates L8 and L9 and the two U.S. human stool isolates (GenBank accessions KY124135 and KY124136). Spanish melon isolate MNSV-Malfa5 is the sole member of group V.

Phylogenetic analysis of amino acid sequences of the Australian isolates and MNSV strains available on GenBank identified five distinct genotype groups for the RdRp, p89 protein (Fig. 2), but only identified four groups for the CP (Fig. 3). Australian isolates Vic Melon, L10, 3948, and 3954 shared the highest amino acid similarity with the Spanish muskmelon strain MNSV-Al (GenBank accession ABC67519.1) for CP and the Dutch cucumber strain for the RdRp protein (GenBank accession NP_041226.1). Isolate 3954 shared the highest amino acid similarity with the Spanish muskmelon MNSV264 strain for the CP (GenBank accession AAR01961.1) and a Brazilian muskmelon strain for the RdRp protein (GenBank accession AXS76158.1). Comparison of amino acid similarity between the Australian isolates L10, Vic Melon, 3948, and 3954 and isolates from group I (Fig. 1) showed 91 to $100 \%$ amino acid similarity across all proteins, whereas isolates in groups II and III shared lower amino acid similarities with these Australian and group I isolates (69 to 75\% for p42 and 77 to 83\% for p89) (Supplementary Tables S6 and S7).

Australian isolates L8 and L9 consistently matched with each other and with MNSV/USA/2014, sharing 98 to $100 \%$ amino acid similarity across all proteins. Comparison with isolates from groups I, II, and III and the remaining four Australian isolates revealed much lower levels of amino acid similarity with L8 and L9 across all of the proteins analyzed. Australian isolates L8 and L9 and isolates from groups I, II, and III shared amino acid similarity of 68 to $74 \%$ p42 and 77 to $78 \%$ for $\mathrm{p} 89$.

Sequence assessment for resistance-breaking regions. Alignment of the 3'-UTR sequences of L8 and L9 with that of MNSV-264 showed high nucleotide similarity (96\%) in the virulence determinant region (stem loop C [SL C]), corresponding to the sequence essential for virus translation in resistant melon (Truniger et al. 2008) (Fig. 4). Conversely, the 3'-UTRs of the group I Australian isolates (3954, 3948, L10, and Vic Melon) were similar to that of the MNSV type avirulent isolate (MNSV-GA), which contained the avirulence determinant essential for virus multiplication in susceptible melon

Table 3. (Continued from previous page)

\begin{tabular}{|c|c|c|c|c|c|c|c|c|c|c|c|c|c|c|c|c|c|}
\hline$\underset{\mathbf{8 8 3 1 4 6}}{\text { KX }}$ & $\begin{array}{c}\text { KY } \\
264755\end{array}$ & $\begin{array}{c}\text { AB } \\
250685\end{array}$ & $\begin{array}{c}\text { AB } \\
250686\end{array}$ & $\begin{array}{c}\text { AB } \\
189943\end{array}$ & $\begin{array}{c}\text { AB } \\
250684\end{array}$ & $\begin{array}{c}\text { AB } \\
189944\end{array}$ & $\begin{array}{c}\text { AB } \\
\mathbf{2 5 0 6 8 7}\end{array}$ & $\underset{122286}{A Y}$ & $\begin{array}{c}\text { AB } \\
232925\end{array}$ & $\begin{array}{c}\text { AB } \\
232926\end{array}$ & $\begin{array}{c}\text { LC } \\
\mathbf{3 1 4 5 8 7}\end{array}$ & $\begin{array}{c}\text { LC } \\
\mathbf{3 1 4 5 8 8}\end{array}$ & $\begin{array}{c}\text { LC } \\
\mathbf{3 1 4 5 8 9}\end{array}$ & $\begin{array}{c}\text { KY } \\
123135\end{array}$ & $\begin{array}{c}\text { KY } \\
124136\end{array}$ & L8 & L9 \\
\hline 95 & 92 & 92 & 93 & 92 & 92 & 93 & 93 & 87 & 72 & 72 & 72 & 72 & 72 & 65 & 65 & 66 & 65 \\
\hline 89 & 87 & 86 & 86 & 87 & 87 & 86 & 86 & 84 & 72 & 72 & 72 & 72 & 72 & 71 & 71 & 71 & 71 \\
\hline 94 & 92 & 91 & 92 & 91 & 92 & 92 & 92 & 87 & 73 & 73 & 72 & 73 & 73 & 66 & 66 & 66 & 66 \\
\hline 93 & 92 & 91 & 92 & 91 & 92 & 92 & 92 & 86 & 72 & 72 & 72 & 72 & 73 & 66 & 65 & 65 & 65 \\
\hline 94 & 92 & 92 & 92 & 92 & 92 & 92 & 92 & 87 & 72 & 73 & 72 & 72 & 72 & 66 & 66 & 66 & 66 \\
\hline 94 & 92 & 91 & 92 & 92 & 92 & 92 & 92 & 87 & 72 & 72 & 72 & 72 & 72 & 66 & 66 & 66 & 66 \\
\hline 94 & 92 & 91 & 91 & 91 & 92 & 92 & 92 & 86 & 73 & 73 & 73 & 72 & 72 & 66 & 66 & 66 & 66 \\
\hline 94 & 92 & 91 & 92 & 92 & 92 & 92 & 92 & 87 & 72 & 72 & 72 & 72 & 72 & 66 & 66 & 66 & 65 \\
\hline 94 & 92 & 91 & 92 & 92 & 92 & 92 & 92 & 87 & 72 & 72 & 72 & 72 & 73 & 65 & 65 & 66 & 65 \\
\hline 92 & 92 & 91 & 91 & 91 & 91 & 91 & 92 & 86 & 72 & 73 & 72 & 73 & 72 & 66 & 66 & 65 & 65 \\
\hline 93 & 91 & 91 & 91 & 91 & 91 & 91 & 91 & 87 & 73 & 72 & 73 & 73 & 72 & 66 & 65 & 66 & 66 \\
\hline 94 & 92 & 91 & 92 & 91 & 91 & 92 & 92 & 87 & 73 & 73 & 73 & 73 & 73 & 66 & 68 & 68 & 65 \\
\hline 94 & 92 & 91 & 91 & 91 & 91 & 91 & 91 & 87 & 73 & 72 & 72 & 73 & 73 & 66 & 66 & 66 & 66 \\
\hline \multirow[t]{17}{*}{98} & 93 & 92 & 93 & 92 & 93 & 93 & 93 & 87 & 72 & 73 & 73 & 72 & 73 & 65 & 65 & 65 & 65 \\
\hline & 92 & 92 & 92 & 92 & 92 & 93 & 93 & 87 & 72 & 72 & 72 & 72 & 72 & 65 & 65 & 65 & 66 \\
\hline & & 91 & 91 & 91 & 91 & 91 & 91 & 86 & 72 & 73 & 72 & 72 & 73 & 66 & 66 & 65 & 65 \\
\hline & & & 97 & 96 & 97 & 96 & 97 & 87 & 73 & 73 & 72 & 73 & 72 & 66 & 66 & 66 & 66 \\
\hline & & & & 96 & 97 & 97 & 97 & 87 & 72 & 73 & 72 & 72 & 72 & 65 & 65 & 65 & 65 \\
\hline & & & & & 97 & 97 & 97 & 87 & 72 & 73 & 73 & 72 & 72 & 66 & 66 & 66 & 65 \\
\hline & & & & & & 99 & 99 & 87 & 72 & 72 & 73 & 72 & 73 & 65 & 65 & 66 & 65 \\
\hline & & & & & & & 100 & 87 & 73 & 73 & 73 & 73 & 74 & 66 & 66 & 66 & 66 \\
\hline & & & & & & & & 87 & 73 & 73 & 73 & 73 & 73 & 66 & 66 & 66 & 66 \\
\hline & & & & & & & & & 73 & 72 & 72 & 72 & 72 & 65 & 65 & 65 & 65 \\
\hline & & & & & & & & & & 97 & 97 & 97 & 97 & 69 & 69 & 68 & 68 \\
\hline & & & & & & & & & & & 97 & 97 & 97 & 69 & 68 & 67 & 67 \\
\hline & & & & & & & & & & & & 98 & 98 & 67 & 67 & 67 & 67 \\
\hline & & & & & & & & & & & & & 98 & 69 & 69 & 67 & 67 \\
\hline & & & & & & & & & & & & & & 68 & 69 & 67 & 67 \\
\hline & & & & & & & & & & & & & & & 99 & 98 & 98 \\
\hline & & & & & & & & & & & & & & & & 99 & 98 \\
\hline
\end{tabular}


(Truniger et al. 2008) (Fig. 4). Finally, the 55-nt sequence at the $5^{\prime}$ proximal end of the 3'-UTR of MNSV-N (GenBank accession KF060715) that was also identified as a resistance-breaking determinant (Miras et al. 2014) could not be identified in the $3^{\prime}$-UTR of any of the Australian isolates.

Detection of $O$. bornovanus and MNSV in bait plants and field samples. Olpidium-like zoospores and resting sporangia were observed using a light microscope in rockmelon seedlings grown in potting media mixed with soil from the MNSV-contaminated Victorian site. The morphology of the structures was suggestive of $O$. bornovanus. Zoosporangia resembling those formed by $O$. nematodae were also observed in seedlings from one soil sample (Fig. 5A). Olpidium-like zoosporangia and resting spores were observed but were not as readily detectable in seedlings grown in the potting mix, vermiculite, or the two negative control treatments (Fig. 5B). In addition, Olpidium-like resting sporangia and zoospores in roots

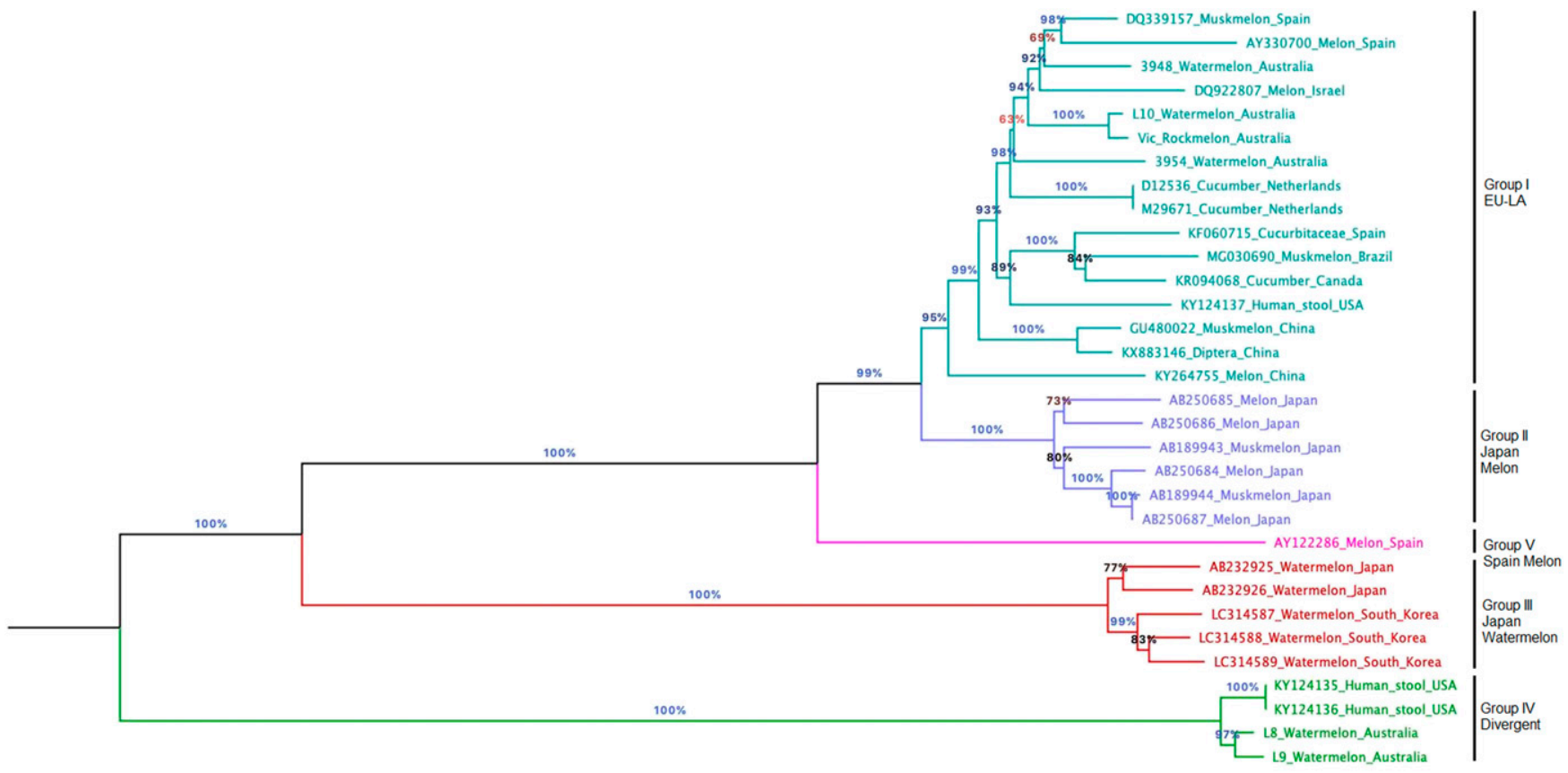

0.03

Fig. 1. Maximum likelihood phylogenetic relationship of full genome sequences of Australian and GenBank Melon necrotic spot virus isolates (Supplementary Table S4). The phylogenetic tree was constructed using MEGA version 6 with 1,000 bootstrap replicates. Genotype groups, current and proposed, are shown. The scale bar represents a genetic distance of 0.03 .

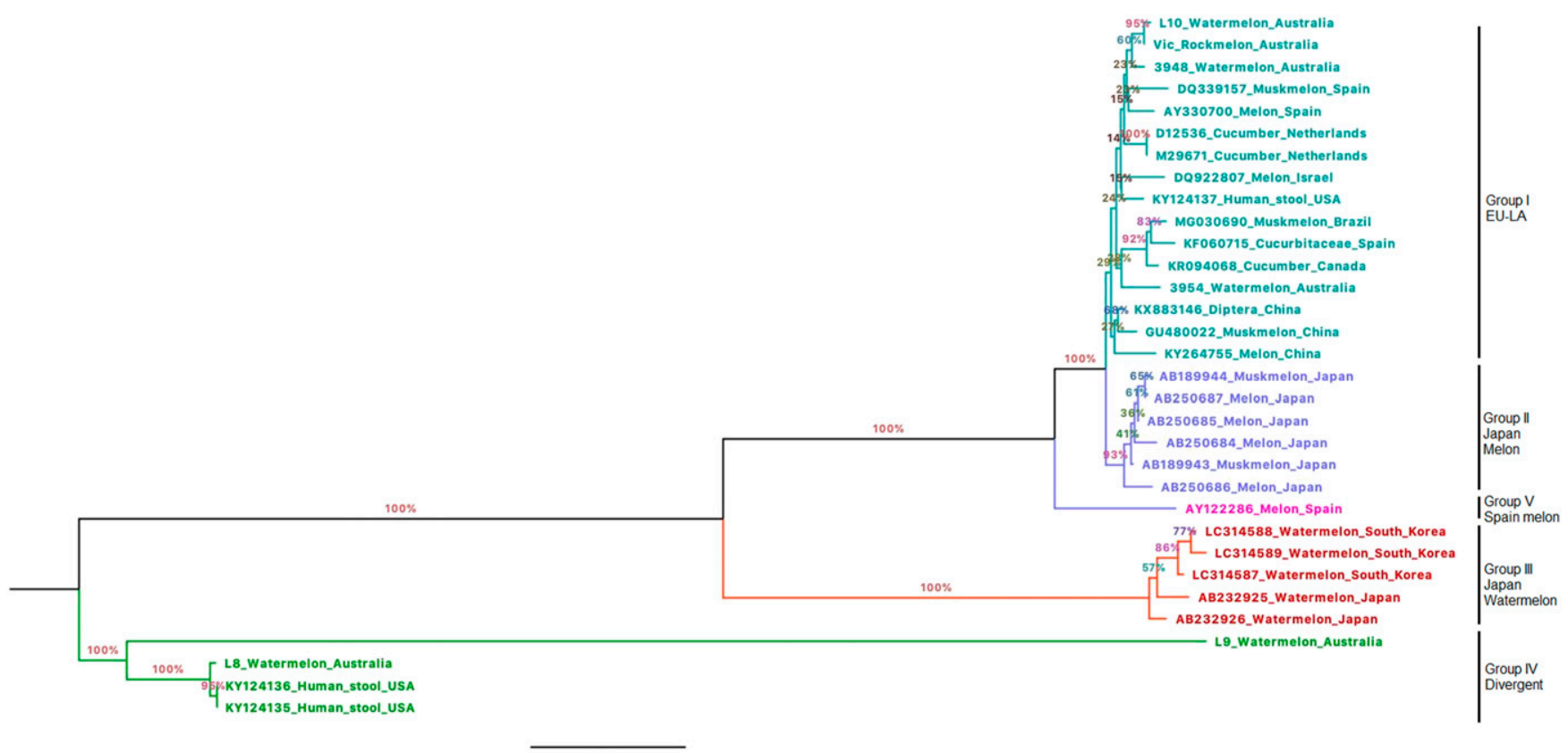

Fig. 2. Maximum likelihood phylogenetic relationship of the complete RNA-dependent RNA polymerase (p89) amino acid sequences of Australian and GenBank Melon necrotic spot virus isolates (Supplementary Table S4). The phylogenetic tree was constructed using MEGA version 6 with 1,000 bootstrap replicates. Genotype groups, current and proposed, are shown. The scale bar represents a genetic distance of 0.03 . 
of sample L9 (watermelon cultivar Royal Armada on Emphasis rootstock) from Dareton, New South Wales, were observed using a light microscope (data not shown). PCR using primers OLPborF/ OLPborR amplified a 977-bp product of the internal transcribed spacer (ITS) region in samples with $O$. bornovanus-like spore structures from both melon and watermelon seedlings grown in soil from Victoria and New South Wales, respectively. Sanger sequencing of the PCR product confirmed the presence of O. bornovanus. Both isolates had $100 \%$ nucleotide sequence similarity to $O$. bornovanus isolates $\mathrm{CH}$ (GenBank accession AB205215.1), BR-01 (GenBank accession EU934040.1), and N2 (GenBank accession AB665758.1). The presence of MNSV was confirmed in the melon seedlings using RT-PCR with the MNSV1/MNSV2 primers.

\section{Discussion}

This study represents the first detection and molecular characterization of MNSV in Australia and the first detection of $O$. bornovanus from soil sampled from an MNSV-contaminated site in Australia.
MNSV. The phylogenetic analyses results presented in the current study resemble those reported by Herrera-Vásquez et al. (2010) in which three distinct genotype groups (EU-LA, Japan melon, and Japan watermelon) were identified based on analysis of nucleotide sequences of the RdRp, $\mathrm{CP}$, and movement protein $\mathrm{p} 7 \mathrm{~A}$. Wu et al. (2016) also identified similar groups based on full-length genomes. However, the inclusion of full-length MNSV genome sequences from a broader geographical area and host groups in this study has expanded the phylogeny and created more definition between groups, reflected in the full genome and the RdRp protein phylogenetic trees that indicate five genotype groups. The $\mathrm{CP}$ analysis only generated four genotype groups implying a higher level of conservation across this region. The usefulness of the $\mathrm{CP}$ region to determine variation between isolates is reduced. To account for the fourth and fifth groups of divergent strains revealed in the full genome and RdRp trees, and the expansion of regions and hosts in which MNSV isolates have been detected, we suggest an update of the nomenclature of the genotype groups suggested by Herrera-Vásquez et al

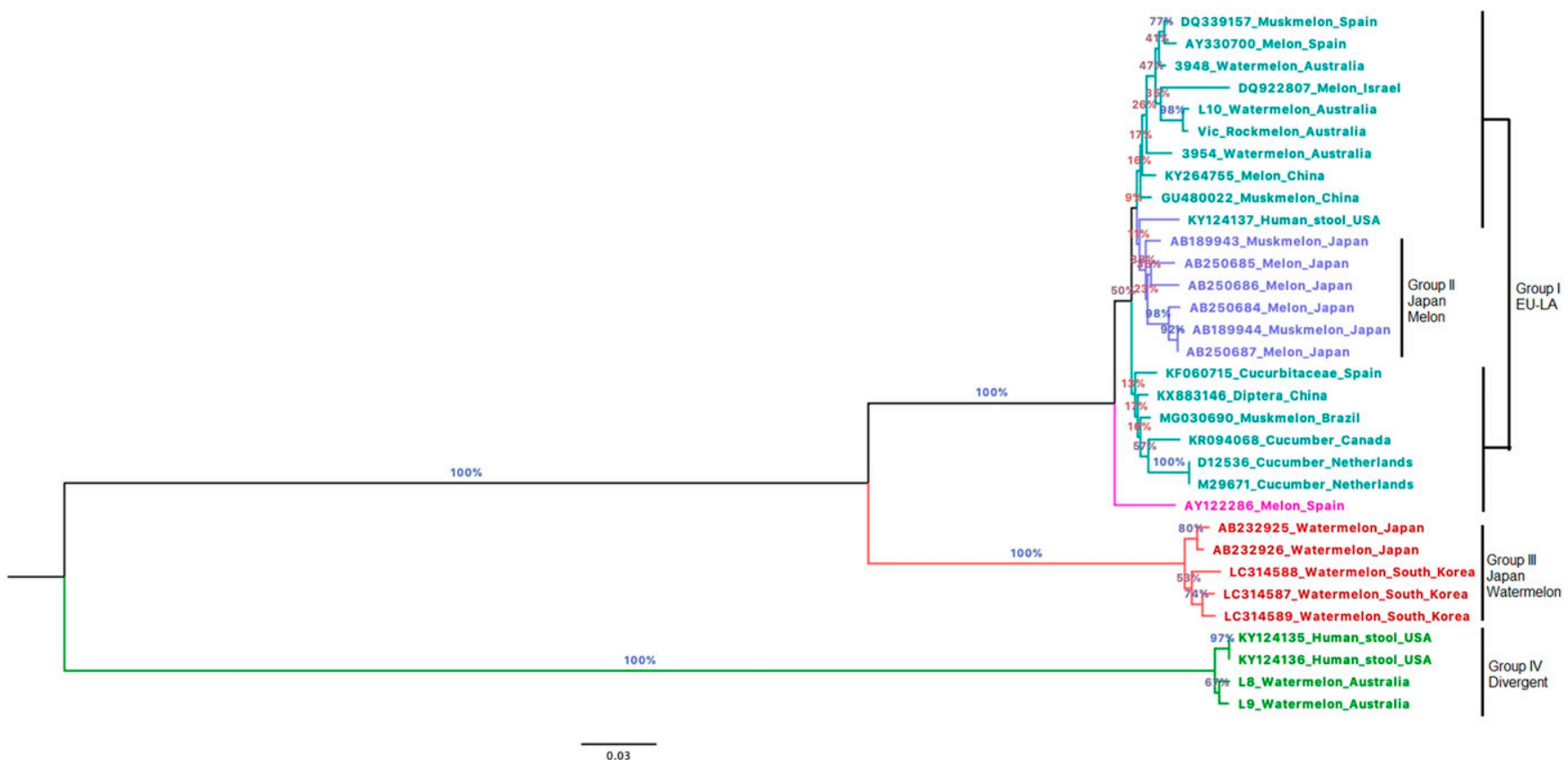

Fig. 3. Maximum likelihood phylogenetic relationship of the complete coat protein (p42) amino acid sequences of Australian and GenBank Melon necrotic spot virus isolates (Supplementary Table S4). The phylogenetic tree was constructed using MEGA version 6 with 1,000 bootstrap replicates. Genotype groups, current and proposed, are shown. The scale bar represents a genetic distance of 0.03 .

\begin{tabular}{|c|c|c|c|}
\hline & Virulence determinant region 1 & Terminal stem loop (SL) of SL C & Virulence determinant region 2 \\
\hline 64_3UTR & 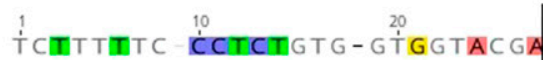 & 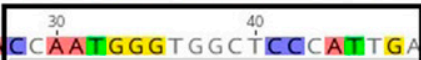 & 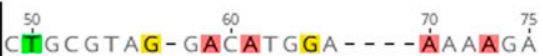 \\
\hline L8_3UTR & TICTTMT CCCCTCTG T G - G TGG TAC GA & CᄃAATGGGTGGCTCC CATT GA & CTG C G TAG - GACATGAG - - - A A A A A A G A \\
\hline L9_3UTR & TMC TTMT CCCCTCTGTG - GTGG TAC GA & CСAATGGGTGGCTCCСATTGA & CTMCGTAG - GACAT GAG - - - A A A A A A G A \\
\hline MNSV-GA_3UTR & $\ldots$ GTGTGTAGTGCGG & TGGCTAACCGTAA & IIGGCGATCGGCTTGGATTTCCGATGA \\
\hline 3954_3UTR & TCCTTGTC $\ldots$ GTGTGTAGTGCGG & TC $\ldots$ TGGCTAACCGTAA & CGGCGTATCGGCTTGAACTTCCGATGA \\
\hline 3948_3UTR & TCCTTGTC $\ldots$ GTGTGTAGTGCGG & TC $\ldots$ TGGCTAACCGTAA & $C G G C G T A T C G A C T T G G A T T T C C A A T G A$ \\
\hline L10_3UTR & TCCTTGTC $\ldots$ GTGTGTAGTGCGG & TC . . TGGCTAACCGTAA & CGGCGTATCGGCTTGAATTTCCTATGA \\
\hline Vic_Rockmelon_3UTR & GTGTGTAGTGCGG & TC $\ldots$ TGGCTAACCGTAA & $C G G C G T A T C G G C T T G A A T T T C C A A T G A$ \\
\hline
\end{tabular}

Fig. 4. Alignment of the $3^{\prime}$-untranslated region (UTR) virulence determinant and terminal stem loop (SL) regions of resistance-breaking Melon necrotic spot virus (MNSV) isolate MNSV-264 (GenBank accession AY330700), MNSV type avirulent isolate (MNSV-GA, GenBank accession D12536), and Australian isolates from Citrullus lanatus (L8, L9, L10, 3948, and 3954), and Cucumis melo (Vic Melon). 
(2010) as follows: group I (EU-LA) comprising melon and cucumber isolates from Europe (Spain, the Netherlands), Israel and China, and a human stool isolate from the United States; group II (Japan melon); group III (Japan watermelon) comprising isolates from Japan and Korea; and group IV, which contains highly divergent strains of MNSV.

The fifth group (group V) present in all of the phylogenetic analyses of this study was limited to one Spanish melon isolate, MNSVMalfa5 (GenBank accession AY122286). Herrera-Vásquez et al. (2010) also observed that this isolate formed a distinct clade with another isolate known as SP-6 when other gene regions were analyzed. The polymerase and CP regions of MNSV-Malfa5 share 94 to $97 \%$ nucleotide identity with isolates in groups I and II. Investigation of the $\mathrm{p} 7 \mathrm{~A}, \mathrm{p} 7 \mathrm{~B}$, and $\mathrm{p} 14$ proteins suggest that these regions have greater variability in the MNSV-Malfa5 isolate, compared with neighboring isolates, resulting in the observed positioning of this isolate in the phylogenetic analyses. Studies investigating the biological and molecular characteristics of MNSV-Malfa5 (Díaz et al. 2003) confirm the phylogenetic positioning of this isolate in the present work.

The four MNSV isolates identified during Australian outbreaks fell into groups I (L10, Vic Melon) and IV (L8, L9), suggesting that there were at least two introductions of MNSV into Australia (Fig. 1). Isolates L8 and L9 also share a high level of sequence identity (99\%) and may have a common origin. Similarly, isolates L10 and Vic Melon share a high level of sequence identity (99\%) and may also have a common origin. The Vic Melon isolate was not detected in cultivar Jaipur seed that was used to grow the affected rockmelon crop and the associated disease was widespread, suggesting that MNSV was present on the farm prior to planting. Seed, from which plants of the watermelon cultivar infected with L10 were grown, was not available for testing to determine whether this was a source of MNSV infection.

Although the seed isolates 3948 and 3954 also clustered with group I strains, they were distinct from L10 and Vic Melon isolates, suggesting that the origin of these outbreak isolates was different from the origin of the isolates in the infected imported seed. Strains in group I have been reported from countries in Asia, Europe, the Americas, and the Middle East and the specific origin of the L10, Vic Melon, 3948, and 3954 isolates is uncertain. Isolate 3948 was more closely related to strains reported from Spain and it is possible that seed was supplied from this region. However, Australia imports cucurbit seed from a range of countries; seed source and seed

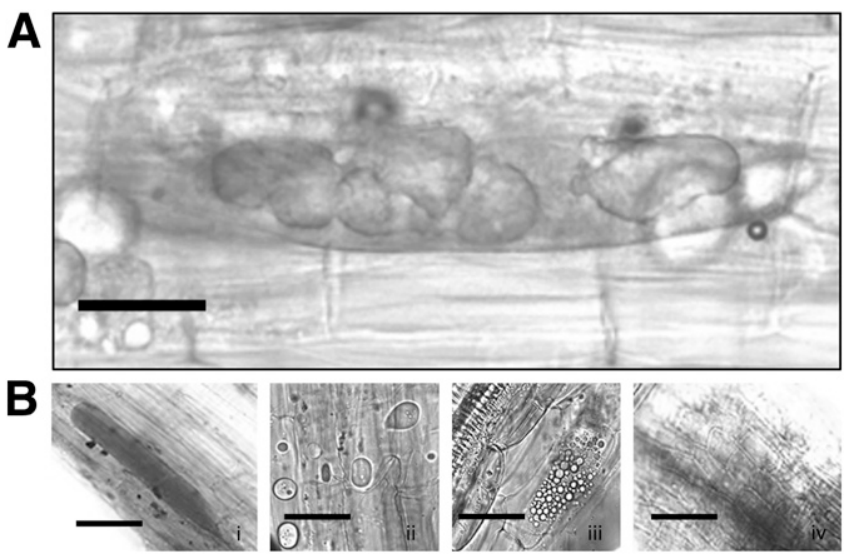

Fig. 5. A, Zoosporangia similar to those formed by Olpidium nematodae were observed by light microscopy $(\times 400)$ in melon cultivar Jaipur roots of seedlings grown in one soil sample from the Melon necrotic spot virus (MNSV)-contaminated farm in Victoria. B, Microscopic observations $(\times 400)$ of melon cultivar Jaipur roots infected with Olpidium sp. in the transmission trial using soil from the MNSVcontaminated farm in Victoria: i, developing zoosporangia, ii, empty zoosporangia, and iii, resting spore-like structures filling the root cell. Similar structures were not observed in root cells of plants grown in vermiculite (iv, negative control). Scale bar, $20 \mu \mathrm{m}$ production areas are not always based at the same location. This can make it difficult to trace the source of seeds and pathogen. Information regarding the source of isolate 3948 seed was not available to the authors.

Group IV contained two divergent MNSV isolates (L8 and L9) that were detected in two different watermelon cultivars from New South Wales in 2012 and 2013, respectively, and two divergent isolates from human stool samples (MNSV/USA/MD/2012, GenBank accession KY124135; MNSV/USA/OR/2014, GenBank accession, KY124136) from the United States (Marine et al. 2017). All four isolates were also closely related to an MNSV strain from Spain (KT962848), for which only a partial genome sequence exists (2,211 nt; Ruiz et al. 2016). Examination of the levels of shared identity of nucleotides of the full genomes (69\%) and amino acid similarity of each of the five proteins of the four group IV isolates compared with MNSV strains from groups I, II, and III, which includes the type MNSV sequence (GenBank accession D12536), raises the question as to whether the group IV isolates are in fact MNSV or a new species within the Gammacarmovirus genus. Species demarcation criteria for the genus Gammacarmovirus (Scheets et al. 2015, 2016) requires $<75 \%$ amino acid identity in the polymerase and CP. This criterion is met for the $\mathrm{CP}$, with amino acid similarity of $73 \%$ compared with the type isolate (GenBank accession NC_001504), but fails to meet the requirement for the polymerase, with a $77 \%$ amino acid similarity with the type isolate. However, analysis of L8, L9, and the human stool isolates using the PASC classification tool (Bao et al. 2014) confirmed MNSV species assignment. Therefore, although L8, L9, and the human stool isolates sit at the border of species demarcation, we consider the Australian group IV isolates to be a distinct strain of MNSV. All New South Wales watermelon samples were collected because they all presented with necrotic spots in stems and leaves. No further work was done to determine whether any of the watermelon MNSV (L8, L9, L10) strains were associated with any variation in symptom expression in other watermelon cultivars or other cucurbit species.

No recombination was detected among Australian isolates of MNSV, suggesting that the diversity observed was attributed to other evolutionary processes and that none of the observed diversity was an artifact of sequencing and genome assembly in this study. The initial analysis identified potential recombination events among some overseas MNSV stains, but it was not supported by further analysis. Interestingly, interfamilial recombination between MNSV and CABYV in the $3^{\prime}$-UTR is thought to have led to the resistancebreaking strain MNSV-N (Miras et al. 2014).

To assess whether the Australian isolates are likely to be resistance breaking, the $3^{\prime}$-UTR region of each isolate was screened for the presence of the virulence determinants identified in resistancebreaking isolates MNSV-264 (GenBank accession AY330700) (Díaz et al. 2002) and MNSV-N (GenBank accession KF060715) (Miras et al. 2014). None of the Australia isolates contained the 55-nt insertion that occurs in the $5^{\prime}$-proximal end of the $3^{\prime}$-UTR of MNSV-N (GenBank accession KF060715), which is associated with resistance breaking (Miras et al. 2014). However, RNA secondary structure predictions in Australian isolates L8 and L9 produced highly similar structures when compared with MNSV-264 and the sequence identity of the SL C, which contains the MNSV virulence determinant region, were also similar (Truniger et al. 2008), suggesting that both Australian isolates may meet the initial genomic requirements for the breakdown of the $n s v$ resistance gene. However, small variations in the primary sequence and structure of the SL C might change the virulence of MNSV strains (Miras et al. 2017). An evaluation of the efficiency of interaction between the SL C of MNSV isolates characterized in this study with the 4E eukaryotic translation initiation factors of resistant melon is required to verify whether they are resistance breaking and have the ability to infect resistant cucurbit varieties used by the Australian melon industry.

O. bornovanus. The presence of O. bornovanus (Sahtiyanci) Karling in Australia is significant for the Australian melon industry, as it represents a significant risk for the long-term establishment and spread of MNSV after the virus is introduced onto a farm through 
contaminated seed or soil, if the fungus is already present. The combination of MNSV-infected seed and the presence of $O$. bornovanus in the growing area can have a significant impact of the rate of MNSV transmission and spread. Vector-assisted seed transmission, in soil that contains the fungal vector $O$. bornovanus and where MNSV-infected seed was grown, increases the incidence of MNSV-infected seedlings (Campbell et al. 1996). Whereas internal MNSV infection, in the absence of the fungus, led to seedling infection rates of $<2 \%$, external contamination of seed by the virus, and availability to the vector for transmission to the seedling root system, increased the infection rate up to $>50 \%$.

The 2016 Victorian MNSV incursion occurred on a property that was planted with the MNSV-susceptible melon cultivar, Jaipur. The Jaipur seed lot tested negative for MNSV (data not shown), and the fungal-MNSV transmission study indicated that $O$. bornovanus was not present or only present at low levels on the seed. This narrative suggests that there was a widespread population of the virus and fungal vector in the soil before the susceptible variety was planted. The fungal-MNSV transmission study showed that both $O$. bornovanus and MNSV can persist long term (>18 months) and remain infective on Australian farms, supporting other overseas studies that also demonstrate similar persistence (de Cara et al. 2008; Tomassoli and Barba 2000). This further highlights the risk of introduction and spread of both the fungus and MNSV to the Australian melon industry.

Strains of $O$. bornovanus within the $O$. bornovanus complex can be host specific to cucumber, melon, and squash, and each has varying ability to vector viruses (Campbell and Sim 1994). Some O. bornovanus strains can be grown on a host not specific to the strain but are not able to satisfactorily multiply or be maintained on that nonspecific host. Host specificity of $O$. bornovanus is defined by the ability of single sporangial isolates to infect, grow, and reproduce in different hosts, quantitatively calculated as the percent increase in zoospores. Phylogenetic analysis of the ITS sequences shows that the Australian O. bornovanus strain isolated in this study aligned into a clade with primarily melon isolates (data not shown), supporting similar phylogenies produced by Herrera-Vásquez et al. (2010). The Australian $O$. bornovanus isolate, sourced from a Victorian melon farm, was able to vector MNSV to bait melon plants; however, the compatibility of this strain with other hosts was not tested.

$O$. bornovanus has commonly been regarded as nonpathogenic (Grogan and Campbell 1966; Sasaya and Koganezawa 2006; Temmink and Campbell 1968); however, one investigation (Stanghellini et al. 2010) showed that this fungus was associated with the decline of melon plants in which MNSV was not detected but had developed significant root rot and a $60 \%$ reduction in vegetative growth 28 days postinoculation with $O$. bornovanus. This suggests that the presence of $O$. bornovanus in melon cultivation regions may play a dual role in the health status of crops as a pathogen and a virus vector.

Further surveillance and characterization of Australian O. bornovanus isolates is required to enable development of management strategies to prevent disease caused by MNSV and spread of the fungal vector in Australia. It is recommended that fungal host specificity and pathogenicity be investigated, and its presence or the presence of other $O$. bornovanus strains in cucurbit production areas in Australia be determined.

\section{Conclusion}

The presence of MNSV and the fungus $O$. bornovanus can form a complex disease matrix that can impact the successful production of cucurbits. The combination of MNSV-infected seed, the long-term viability of the virus in soil, the potential for resistance-breaking strains of MNSV, the presence of $O$. bornovanus and its ability to acquire virus particles via adsorption to the zoospore, and the potential pathogenicity of the fungus are all determinants in management systems that may need to be adopted. Field sanitation after virus incursion is vital; the use of clean seed is no guarantee for virus-free plants if the fungal vector and the virus remain in situ, and even the longterm presence of the vector may impact plant health.

At the current time, MNSV is a regulated quarantine pest for Australia as a result of its restricted distribution; consequently, seed is tested for MNSV and other viruses at the Australian border to prevent further incursions. The detection of MNSV in imported seed highlights the risk of further introductions posed by seed and it is recommended that seed continue to be regulated at the Australian border. Growers should ensure that seed is obtained from reputable sources and has been tested for MNSV. The presence of O. bornovanus on MNSVaffected farms highlights the increased risk of disease caused by virus-contaminated seed, further supporting the need for seed testing.

\section{Literature Cited}

Ali, A., Abdalla, O., Bruton, B., Fish, W., Sikora, E., Zhang, S., and Taylor, M. 2012a. Occurrence of viruses infecting watermelon, other cucurbits, and weeds in the parts of southern United States. Plant Health Prog. 13.

Ali, A., Mohammad, O., and Khattab, A. 2012b. Distribution of viruses infecting cucurbit crops and isolation of potential new virus-like sequences from weeds in Oklahoma. Plant Dis. 96:243-248.

Altschul, S. F., Madden, T. L., Schaffer, A. A., Zhang, J., Zhang, Z., Miller, W., and Lipman, D. J. 1997. Gapped BLAST and PSI-BLAST: A new generation of protein database search programs. Nucleic Acids Res. 25:3389-3402.

Avgelis, A. 1989. Watermelon necrosis caused by a strain of melon necrotic spot virus. Plant Pathol. 38:618-622.

Ayo-John, E. I., Olorunmaiye, P. M., Odedara, O. O., Dada, O. B., Abiola, K. O. and Oladokun, J. O. 2014. Assessment of field-grown cucurbit crops and weeds within farms in south-west Nigeria for viral diseases. Not. Sci. Biol. 6:321-325.

Bankevich, A., Nurk, S., Antipov, D., Gurevich, A. A., Dvorkin, M., Kulikov, A. S., Lesin, V. M., Nikolenko, S. I., Pham. S., and Prjibelski, A. D. 2012 SPAdes: a new genome assembly algorithm and its applications to single-cell sequencing. J. Comput. Biol. 19:455-477.

Bao, Y., Chetvernin, V., and Tatusova, T. 2014. Improvements to pairwise sequence comparison (PASC): A genome-based web tool for virus classification. Arch. Virol. 159:3293-3304.

Boni, M. F., Posada, D., and Feldman, M. W. 2007. An exact nonparametric method for inferring mosaic structure in sequence triplets. Genetics 176: $1035-1047$

Bos, L., Van Dorst, H. J. M., Huttinga, H., and Maat, D. Z. 1984. Further characterization of melon necrotic spot virus causing severe disease in glasshouse cucumbers in the Netherlands and its control. Neth. J. Plant Pathol. 90:55-69.

Campbell, R. N., and Sim, S. T. 1994. Host specificity and nomenclature of Olpidium bornovanus (=Olpidium radicale) and comparisons to Olpidium brassicae. Can. J. Bot. 72:1136-1143.

Campbell, R. N., Wipf-Scheibel, C., and Lecoq, H. 1996. Vector-assisted seed transmission of melon necrotic spot virus in melon. Phytopathology 86: 1294-1298.

Carmichael, J. W. 1955. Lacto-fuchsin: A new medium for mounting fungi Mycologia 4:611.

Coudriet, D. L., Kishaba, A. N., and Bohn, G. W. 1981. Inheritance of resistance to muskmelon necrotic spot virus in a melon aphid-resistant breeding line of muskmelon. J. Am. Soc. Hortic. Sci. 106:789-791.

Darriba, D., Taboada, G. L., Doallo, R., and Posada, D. 2012. jModelTest 2: more models, new heuristics and parallel computing. Nat. Methods 9:772.

de Cara, M., Lopez, V., Cordoba, M. C., Santos, M., Jorda, C., and Tello, J. C. 2008. Association of Olpidium bornovanus and Melon necrotic spot virus with vine decline of melon in Guatemala. Plant Dis. 92:709-713.

Díaz, J. A., Bernal, J. J., Moriones, E., and Aranda, M. A. 2003. Nucleotide sequence and infectious transcripts from a full-length cDNA clone of the carmovirus Melon necrotic spot virus. Arch. Virol. 148:599-607.

Díaz, J. A., Nieto, C., Moriones, E., and Aranda, M. A. 2002. Spanish Melon necrotic spot virus isolate overcomes the resistance conferred by the recessive $n s v$ gene of melon. Plant Dis. 86:694.

Díaz, J. A., Nieto, C., Moriones, E., Truniger, V., and Aranda, M. A. 2004. Molecular characterization of a Melon necrotic spot virus strain that overcomes the resistance in melon and non-host plants. Mol. Plant-Microbe Interact. 17:668-675.

Edgar, R. C. 2004. MUSCLE: Multiple sequence alignment with high accuracy and high throughput. Nucleic Acids Res. 32:1792-1797.

Gibbs, M. J., Armstrong, J. S., and Gibbs, A. J. 2000. Sister-scanning: A Monte Carlo procedure for assessing signals in recombinant sequences. Bioinformatics 16:573-582.

Gonzalez-Garza, R., Gumpf, D. J., Kishaba, A. M., and Bohn, G. W. 1979. Identification, seed transmission, and host range pathogenicity to a California isolate of melon necrotic spot virus. Phytopathology 69:340-345.

Green, M. J., Thompson, D. A., and MacKenzie, D. J. 1999. Easy and efficient DNA extraction from woody plants for the detection of phytoplasmas by polymerase chain reaction. Plant Dis. 83:482-485.

Grogan, R. G., and Campbell, R. N. 1966. Fungi as vectors and hosts of viruses Annu. Rev. Phytopathol. 4:29-52.

Gu, Q.-S., Bao, W.-H., Tian, Y.-P., Prins, M., Yang, H.-X., Lu, J., Liu, L.-F., and Peng, B. 2008. Melon necrotic spot virus newly reported in China. Plant Pathol. 57:765.

Herrera-Vásquez, J. A., Cebrian, M. D., Alfaro-Fernandez, A., Cordoba-Selles, M. D., and Jorda, C. 2009a. Multiplex PCR assay for the simultaneous 
detection and differentiation of Olpidium bornovanus, $O$. brassicae, and $O$. virulentus. Mycol. Res. 113:602-610.

Herrera-Vásquez, J. A., Córdoba-Sellés, M. C., Cebrián, M. C., Alfaro-Fernández, A., and Jordá, C. 2009b. Seed transmission of Melon necrotic spot virus and efficacy of seed-disinfection treatments. Plant Pathol. 58:436-442.

Herrera-Vásquez, J. A., Córdoba-Sellés, M. C., Cebrián, M. C., Rosselló, J. A., Alfaro-Fernández, A., and Jordá, C. 2010. Genetic diversity of Melon necrotic spot virus and Olpidium isolates from different origins. Plant Pathol. 59:240-251.

Hibi, F., Furuki, I., Honda, Y., Saito, Y., and Komuro, Y. 1980. Relationship between cucumber necrosis virus and melon necrotic spot virus. 2. Properties of the viruses and serology. Ann. Phytopathol. Soc. Jpn. 46:419.

Hibi, T., and Furuki, I. 1985. Melon necrotic spot virus. Descriptions of Plants Viruses No. 302. Association of Applied Biologists, Wellesbourne, UK.

Kinoti, W., Constable, F., Nancarrow, N., Plummer, K., and Rodoni, B. 2017b. Analysis of intra-host genetic diversity of Prunus necrotic ringspot virus (PNRSV) using amplicon next generation sequencing. PLoS One 12:e0179284.

Kinoti, W. M., Constable, F. E., Nancarrow, N., Plummer, K. M., and Rodoni, B. 2017a. Generic amplicon deep sequencing to determine Ilarvirus species diversity in Australian Prunus. Front. Microbiol. 8:1219.

Kishi, K. 1966. Necrotic spot of melon, a new virus disease. Ann. Phytopathol. Soc. Jpn. 57:558-567.

Köklü, G., and Yilmaz, O. 2006. Occurrence of cucurbit viruses on field-grown melon and watermelon in the Thrace region of Turkey. Phytoprotection 87: 123-130.

Kubo, C., Nakazono-Nagaoka, E., Hagiwara, K., Kajihara, H., Takeuchi, S., Matsuo, K., Ichiki, T. U., and Omura, T. 2005. New severe strains of Melon necrotic spot virus: Symptomatology and sequencing. Plant Pathol. 54:615-620.

Li, R., Zheng, Y., Fei, Z., and Ling, K.-S. 2015. Complete genome sequence of an emerging melon necrotic spot virus isolate infecting greenhouse cucumber in North America. Genome Announc. 3:e00775-15.

Louws, F. J., Rivard, C. L., and Kubota, C. 2010. Grafting fruiting vegetables to manage soilborne pathogens, foliar pathogens, arthropods and weeds. Sci. Hortic. (Amsterdam) 127:127-146.

MacKenzie, D. J., McLean, M. A., Murkerji, S., and Green, M. 1997. Improved RNA extraction from woody plants for the detection of viral pathogens by reverse transcription-polymerase chain reaction. Plant Dis. 81:222-226.

Mallor, C., Alvarez, M., and Luis-Arteaga, M. 2003. A resistance to systemic symptom expression of melon necrotic spot virus in melon. J. Am. Soc. Hortic. Sci. 128:541-547.

Mallor Giménez, C., Alvarez, J. M., and Luis-Arteaga, M. 2003. Inheritance of resistance to systemic symptom expression of Melon necrotic spot virus (MNSV) in Cucumis melo L. 'Doublon'. Euphytica 134:319-324.

Marine, R., Castro, C., Magaña, L., Ng, T. F. F., Aswath, K., Collins, N., Park, G. W., Vinjé, J., and Oberste, M. S. 2017. Genomic characterization of three melon necrotic spot viruses detected in human stool specimens. Genome Announc. 5:e01758-e16.

Martin, D., Williamson, C., and Posada, D. 2005. RDP2: Recombination detection and analysis from sequence alignment. Bioinformatics 21:260-262.

Martin, D. P., Murrell, B., Golden, M., Khoosal, A., and Muhire, B. 2015. RDP4: Detection and analysis of recombination patterns in virus genomes. Virus Evol. 1:vev003.

Matsuo, K., Kameya-Iwaki, M., and Ota, T. 1991. Two new strains of melon necrotic spot virus. Ann. Phytopathol. Soc. Jpn. 57:558-567.

Miras, M., Sempere, R. N., Kraft, J. J., Miller, W. A., Aranda, M. A., and Truniger, V. 2014. Interfamilial recombination between viruses led to acquisition of a novel translation-enhancing RNA element that allows resistance breaking. New Phytol. 202:233-246.

Miras, M., Truniger, V., Querol-Audi, J., and Aranda, M. A. 2017. Analysis of the interacting partners eIF4F and 3'-CITE required for Melon necrotic spot virus cap-independent translation. Mol. Plant Pathol. 18:635-648.

Moura, M. C. F., Holanda, I. S. A., Sales Júnior, R., Queiroz, A. P. O., Araújo, E. O. A., Oliveira, G. D. C., Nunes, G. H. S., Nagata, T., and Negreiros, A. M. P. 2018. First report of Melon necrotic spot virus in melon plantations in Brazil. Plant Dis. 102:1048.

Muhire, B. M., Varsani, A., and Martin, D. P. 2014. SDT: A virus classification tool based on pairwise sequence alignment and identity calculation. PLoS One 9:e108277.

Nieto, C., Morales, M., Orjeda, G., Clepet, C., Monfort, A., Sturbois, B., Puigdomènech, P., Pitrat, M., Caboche, M., Dogimont, C., Garcia-Mas, J., Aranda, M. A., and Bendahmane, A. 2006. An eIF4E allele confers resistance to an uncapped and non-polyadenylated RNA virus in melon. Plant J. 48:452-462.

Ohki, T., Akita, F., Mochizuki, T., Kanda, A., Sasaya, T., and Tsuda, S. 2010. The protruding domain of the coat protein of Melon necrotic spot virus is involved in compatibility with and transmission by the fungal vector Olpidium bornovanus. Virology 402:129-134.

Ohshima, K., Yamaguchi, Y., Hirota, R., Hamamoto, T., Tomimura, K., Tan, Z., Sano, T., Azuhata, F., Walsh, J. A., Fletcher, J., Chen, J., Gera, A., and Gibbs, A. 2002. Molecular evolution of Turnip mosaic virus: Evidence of host adaptation, genetic recombination and geographical spread. J. Gen. Virol. 83: 1511-1521.

Padidam, M., Sawyer, S., and Fauquet, C. M. 1999. Possible emergence of new geminiviruses by frequent recombination. Virology 265:218-225.

Posada, D. 2002. Evaluation of methods for detecting recombination from DNA Sequences: Empirical data. Mol. Biol. Evol. 19:708-717.

Rambaut, A. 2012. FigTree version 1.4.0: Tree Figure Drawing Tool. http:// tree.bio.ed.ac.uk/software/figtree/

Rambaut, A., Suchard, M. A., Xie, D., and Drummond, A. J. 2014. Tracer, version 1.6. http://beast.bio.ed.ac.uk/Tracer

Riviere, C. J., and Rochon, D. M. 1990. Nucleotide sequence and genomic organization of melon necrotic spot virus. J. Gen. Virol. 71:1887-1896.

Rochon, D. 2009. Fungal transmission of plant viruses. Curr. Protoc. Microbiol. 12:16B.4.1-16B.4.17.

Ronquist, F., Teslenko, M., van der Mark, P., Ayres, D. L., Darling, A., Hohna, S., Larget, B., Liu, L., Suchard, M. A., and Huelsenbeck, J. P. 2012. MrBayes 3.2 Efficient Bayesian phylogenetic inference and model choice across a large model space. Syst. Biol. 61:539-542.

Ruiz, L., Crespo, O., Simon, A., Gomez, J., and Janssen, D. 2016. First report of a novel melon necrotic spot virus watermelon strain in Spain. Plant Dis. 100: 1031.

Sambrook, J., Fritsch, E., and Maniatis, T. 1989. Molecular Cloning: A Laboratory Manual. Cold Spring Harbor Laboratories, Cold Spring Harbor, NY.

Sasaya, T., and Koganezawa, H. 2006. Molecular analysis and virus transmission tests place Olpidium virulentus, a vector of Mirafiori lettuce big-vein virus and tobacco stunt virus, as a distinct species rather than a strain of Olpidium brassicae. J. Gen. Plant Pathol. 72:20-25.

Scheets, K., Jordan, R., White, K. A., and Hernandez, C. 2015. Pelarspovirus, a proposed new genus of plant viruses in the family Tombusviridae. Arch. Virol. 160:2385-2393.

Scheets, K., White, A., Rubino, L., Martelli, G., and Rochon, D. 2016. ICTV taxonomic proposal 2015.007a-rP. Divide the genus Carmovirus into three new genera: Alphacarmovirus, Betacarmovirus, and Gammacarmovirus. https://talk.ictvonline.org/ICTV/proposals/2015.007a-rP.A.v1.split_ Carmovirus.pdf

Sela, N., Lachman, O., Reingold, V., and Dombrovsky, A. 2013. A new cryptic virus belonging to the family Partitiviridae was found in watermelon coinfected with melon necrotic spot virus. Virus Genes 47:382-384.

Smith, J. M. 1992. Analyzing the mosaic structure of genes. J. Mol. Evol. 34: 126-129.

Stanghellini, M. E., Mathews, D. M., and Misaghi, I. J. 2010. Pathogenicity and management of Olpidium bornovanus, a root pathogen of melons. Plant Dis. 94:163-166.

Tamura, K., Stecher, G., Peterson, D., Filipski, A., and Kumar, S. 2013. MEGA6: Molecular Evolutionary Genetics Analysis version 6.0. Mol. Biol. Evol. 30: $2725-2729$

Temmink, J. H. M., and Campbell, R. N. 1968. The ultrastructure of Olpidium brassicae. I. Formation of sporangia. Can. J. Bot. 46:951-965.

Tomassoli, L., and Barba, M. 2000. Occurrence of melon necrotic spot carmovirus in Italy. Bull. OEPP 30:279-280.

Tomlinson, J. A., and Thomas, B. J. 1986. Studies on melon necrotic spot virus disease of cucumber and on the control of the fungus vector (Olpidium radicale). Ann. Appl. Biol. 108:71-80.

Truniger, V., Nieto, C., Gonzalez-Ibeas, D., and Aranda, M. 2008. Mechanism of plant eIF4E-mediated resistance against a Carmovirus (Tombusviridae): Capindependent translation of a viral RNA controlled in cis by an (a)virulence determinant. Plant J. 56:716-727.

Wu, H., Wen, S., Hong, N., Veronica, T., and Gu, Q. 2016. Complete genome sequence of a Chinese isolate of Melon necrotic spot virus and its phylogenetic relationship. J. Phytopathol. 164:704-709.

Yakoubi, S., Desbiez, C., Fakhfakh, H., Wipf-Scheibel, C., Marrakchi, M., and Lecoq, H. 2008. First report of Melon necrotic spot virus on melon in Tunisia. Plant Pathol. 57:386.

Yoshida, K., Goto, T., Nemoto, M., and Tsuchizaki, T. 1980. Five viruses isolated from melon (Cucumis melo L.) in Hokkaido. Ann. Phytopathol. Soc. Jpn. 46: 339-348.

Zheng, Y. X., Chen, C. C., and Jan, F. J. 2011. First report of Carnation mottle virus in Phalaenopsis orchids. Plant Dis. 95:354. 